\title{
Modeling Psychology in Islamic Wealth Management
}

\author{
Ahmed Hamed Al-Abbadi ${ }^{1} \&$ Adam Abdullah ${ }^{1}$ \\ ${ }^{1}$ IIUM Institute of Islamic Banking and Finance, International Islamic University Malaysia, Kuala Lumpur, \\ Malaysia \\ Correspondence: Ahmed Hamed Al-Abbadi, Institute of Islamic Banking and Finance, International Islamic \\ University Malaysia, Kuala Lumpur, 53100, Malaysia. Tel: 60-3-6196-4185. E-mail: \\ ahmadhalabbadi@gmail.com
}

Received: July 25, 2017

Accepted: August 19, 2017

Online Published: September 5, 2017

doi:10.5539/ijef.v9n10p64

URL: https://doi.org/10.5539/ijef.v9n10p64

\begin{abstract}
This paper proposes a conceptual framework for modeling psychology in Islamic wealth management. Incorporating psychology into finance would significantly contribute to our understanding of the behavior of individual investors as well as market behavior. Utilizing the findings of behavioral finance and financial therapy, along with industry megatrends, Islamic wealth management could step further in fulfilling its ultimate objective of promoting social welfare. This is can be achieved by exploring and identifying the psychological factors that affect the clients' decision-making and then behaviorally and cognitively helping them to engage in socially-responsible investments, projects and initiatives. In operationalizing this model, financial advisors/wealth managers should adopt a comprehensive client discovery and profiling method and apply Fintech innovations in producing complex analytics and thereby enriching the client experience.
\end{abstract}

Keywords: Islamic finance, wealth management, psychology, behavioral finance, financial therapy

\section{Introduction}

Human nature is uniquely complex, as it consists of various dimensions that cannot be explained by a simple, cut-and-dried and easy set of rules that are applied equally to humans and other creatures and objects. This oversimplification of the phenomena around us, left us with numerous unanswered questions. Therefore, multi-dimensional study of human nature and its manifestations in real-life is thus, crucial as it represents the substance of the human nature that gives due respect to it (Al-Masiri, 2006).

The multi-dimensional study of human behavior emphasizes the interdependence between social sciences whose problems can be accurately addressed and solved from an interdisciplinary point of view. Evidently, developing new fields that integrase more than one social science has proved its success. Integrating psychology into other social sciences such as politics, law, sociology and economics is among the widely common approach and it has produced significant and fruitful outcomes that benefit many concerned parties from politicians and economists to authorities, social leaders and thinkers.

Traditional economics tend to compartmentalize its disciplines including macroeconomics, microeconomics and finance (E. Baker, 2004), which led to missing the linkage between economics, finance and other social sciences including psychology. Notably, psychology was a central component of neoclassical economics before Pareto's reformulation in 1930s (Bruni \& Sugden, 2007), however, it has been relegated afterwards until the advent of modern behavioral economics and finance in the 1970s. This shift to behavioral finance by economists comes from realizing the complexities of human psychology and consequent limitations of the model of man as a rational maximizer of his satisfactions (Posner, 2013).

The incorporation of psychology in finance has been witnessed in numerous fields including wealth management. As Islamic wealth management is exposed to most trends as well as limitations, constraints and threats that are facing conventional counterpart, the usefulness of incorporating psychology is present in both of them. Nevertheless, having broad and ultimate socioeconomic objectives, Islamic wealth management has some unique perspectives on the conceptions and applications of psychology in its spectrum.

Recent statistics showed how severe is the wealth gap in the world as the top one percent of the world own roughly the half of the world wealth, while around seventy three percent (73\%) own only $2.4 \%$ of the global wealth (Credit Suisse, 2016). Promoting social welfare as an ultimate socioeconomic objective of Islamic 
finance in general and Islamic wealth management in particular (Ahmed, 2013; Farooq, 2014) is meant to be a solution to this unequitable distribution of wealth, yet the reality has shown no progress toward achieving this objective.

Islamic wealth management can potentially play an important role in promoting social welfare and simultaneously obtain a greater competitive and sustainable advantage when its practitioners take further steps to institutionalize such objectives and values in an operating business model. Many studies have discussed the dichotomy between the ultimate Shariah objectives and the current practice of Islamic finance, yet very few studies have attempted to discuss the inner factors affecting the occurance of such dichotomy.

As Islamic and conventional wealth management is founded on providing personalized financial services to wealthy individuals, it is significant to explore influence of various inner/ psychological factors affecting their clients' financial decision-making. Islamic wealth management as a value-based discipline is supposed to utilize this exploration of the psychological factors not only to fulfill the clients needs and goals, but also to address the unspoken reasons of why Muslim wealthy people who own the overwhelming percentage of Muslims wealth (Edbiz, 2016; Farooq, 2014) barely contribute to their societies. Thus, the purpose of this paper is to propose a model that is based on exploring the psychological factors affecting the financial decisions of Islamic wealth management clients and how could this exploration be utilized in stepping further toward promoting social welfare.

After this introduction, section two thematically reviews the literature of several relevant topics, followed by section three that discusses the theoretical framework and model description. The paper ends with some concluding remarks.

\section{Literture Review}

The nature of this research is inter-disciplinary as it attempts to a produce a model that is essentially based on the interaction between Islamic worldview and precepts, finance and psychology. The literature that studies the interaction between these three elements is rare, which leads to a huge literature of different topics that should be carefully reviewed in order to produce a representative, relevant and brief selection of literature. In this literature review, thematic approach is chosen as it deems appropriate for this kind of interdisciplinary researches. Therefore, each theme discusses a topic that must be reviewed in order to comprehend the concepts presented in this paper.

\subsection{Traditional Finance}

Traditional finance draws its philosophical foundations from neoclassical economics, that fundamentally relies on the concept of "homoeconomicus" (Calnitsky \& Dupuy-spencer, 2013). Expected Utility Theory (EUT) of Neumann and Morgenstern (1947) came to further specify and explain the concept of homoeconomicus. Both of them suggest that an individual rationally seeks his/her own self-interest by maximizing his/her utility when making decisions with economic outcomes under uncertainty (Asutay, 2007; Calnitsky \& Dupuy-spencer, 2013; Yamagishi, Li, Takagishi, Matsumoto, \& Kiyonari, 2014; Neumann \& Morgenstern, 1947). The wide acceptance of EUT among economists is due to its simplification of economic analysis and its quantifiability of the findings (Pompian, 2012).

Having EUT as a theory that attempts to explain the individual behavior, another widely applied hypothesis that attempt to explain the market behavior is the Efficient Market Hypothesis (EMH) developed by Fama (1970). EMH argues that market is efficient when the prices are fairly valued and fully reflect the available information and thus, investors are not able to outperform the market. Other dominant classical theories include "the arbitrage principles of Miller and Modigliani, the portfolio principles of Markowitz, the capital asset pricing theory of Sharpe, Lintner, and Black, and the option-pricing theory of Black, Scholes, and Merton." (Statman, 1999, p. 19).

Despite their great usefulness, classical theories lack the explanatory power due to their simplification of the human behavior and their marginalization of the other factors such as psychological factors that can have a great impact on financial decision-making. Consequently, behavioral finance proponents attempt to humanize finance by adding more complex explanations of the financial phenomena that has a greater explanatory and predictive power than the traditional finance.

\subsection{Behavioral Finance}

Behavioral finance is a paradigm shift, from a neoclassical-based framework to a framework that primarily incorporates psychology as well as sociology and anthropology in finance and investment theories (Shiller, 1998; Shefrin, 2010) to provide more realistic and descriptive models of the individuals and markets behaviors. This 
shift to behavioral finance by many economists comes from realizing the complexities of human psychology and consequent limitations of the model of man as a rational maximizer of his satisfactions (Posner, 2013). Unlike the normative theories of neoclassical economics, behavioral finance theories are positive, descriptive and prescriptive in which they attempt to explain how people actually behave instead of how should they behave (Kahneman \& Tversky, 1979; Barberis \& Thaler, 2003; De Bondt, Muradoglu, Shefrin, \& Staikouras, 2008; Shefrin, 2010).

The advent of the modern behavioral finance was when Kahneman and Tversky (1979) introduced the Prospect Theory that occupies a central position at the heart of behavioral finance in the same way that EUT has in the neoclassical finance. The theory criticizes the EUT as a descriptive model of human behavior under risk that is caught inconsistent under certain effects. The theory proposes some primary effects that influence decision-making process and deviate it from optimality to normality.

In shaping the boundaries of behavioral finance. Pompian (2012) and Posner (2013) differentiated between the micro and macro behavioral finance in which the former is about individuals behavior, while the latter is about market behavior. Furthermore, De Bondt et al. (2008) summarized the building blocks of behavioral finance to sentiment and behavioral preferences that explain the individual investor behavior, as opposed to EUT, and limits to arbitrage that explains the market behavior as opposed to the EMH.

Individual and professional investors are prone to cognitive and emotional baises (Pompian, 2012; Hens \& Meier) that deviate them from making investment decisions. Examples of the most common biases are the disposition effect, regret aversion, loss aversion, cognitive dissonance, anchoring, mental accounting, overconfidence, overand underreaction, confirmation biases, herding behavior and hindsight bias (Shiller, 1998; Pompian, 2012; Johnson \& Horan, 2013; Hens \& Meier, 2015). Thus, sentiment and behavioral preferences are major determinants of the individuals' behavior and thus should be taken into due consideration.

Shefrin (2000) used psychological research to help understand the human behavior that guides stock selection, financial services, and corporate financial strategy at the individual level. Complementarily, applying some factors from psychology, sociology and social psychology, Shiller $(2003,2005)$ argued that many anomalies that have been continuously discovered are considered as evidences against the EMH. In their efforts of humanizing finance, behavioral finance introduced behaviorally-modified economic theories such as Behavioral Asset Pricing Model (Shefrin \& Statman, 1994; Shefrin, 2008; Statman, Anginer, \& Fisher, 2008), Behavioral Corporate Finance (Shefrin, 2001; 2010) and Behavioral Portfolio Theory (Shefrin \& Statman, 2000).

\subsection{Financial Therapy}

Despite it attempts to produce a comprehensive theory of individual and market behaviors, behavioral finance dominantly focuses on the investing side of finance and gives a minimal attention to the other finances such as financial planning. Realizing the need for an ultra-holistic financial advice that encompasses all aspects and factors that can have an impact on financial matters, a diverse group from different fields introduced the newly known financial therapy (Grable \& Archuleta, 2011; Grable, McGill, \& Britt, 2010).

Financial therapy is defined by its founding association as "the integration of cognitive, emotional, behavioral, relational, and economic aspects that influence financial well-being, and ultimately, quality of life by understanding the interpersonal and intrapersonal aspects of money and utilize this knowledge to help clients achieve their financial goals" (Financial Therapy Association, 2015, p. 1). Hence, financial therapists provide a complex and comprehensive financial advice that inseparably touches all aspects influencing client's financial health with the aim of improving not only financial health but also the quality of life (Archuleta et al., 2012)

This multidisciplinary nature of financial therapy utilizes aspects and mechanisms from various disciplines that primarily consist of financial planning, mental health and psychotherapy (Archuleta et al., 2012; Delgadillo \& Britt, 2015; B. T. Klontz, Britt, \& Archuleta, 2015). Initially, financial therapy adopted collaborative strategies in which a financial planner and a therapist simultaneously work with a client in the same session to address the interfering issues related to financial life, henceforth, cross training in both mental health and financial planning replaced the collaborative approach (Archuleta et al., 2012: Mccoy, Ross, \& Goetz, 2013).

Archuleta et al. (2012) and Klontz et al. (2015) pointed out that as psychotherapy has no universally accepted theory, financial therapist can adopt any founded modalities and theories of psychotherapy. The different psychotherapy models include -but not limited to- cognitive behavioral therapy, solution-focused therapy, strategic therapy, psychodynamic therapy, experiential therapy, systemic therapy, collaborative relational therapy (Britt et al., 2015b; Grable et al., 2011).

Some new models tended to integrate more than psychotherapy approaches to come up with more 
comprehensive model of financial therapy. For instance The first model is the Ford Financial Empowerment Model of (Ford, Baptist, \& Archuleta, 2011) that integrated cognitive-behavioral, narrative, and experiential therapies, and financial counseling. On the other hand, Mccoy et al. (2013) developed the narrative model that stands on integrating narrative therapy and cognitive-behavioral interventions with the six-steps of CFP financial planning.

\subsection{Islamic Perspectives on Behavioral Finance and Financial Therapy}

As has been shown, a rudimentary difference between behavioral finance and traditional finance is the notion of human nature that drives financial decision-making under uncertainty. Islamic behavioral finance or Islamic financial therapy are no exception and as faith-based disciplines, their philosophical foundations should be in line with the percepts of Islam and its worldview, particularly, its perspective of human nature.

Musse, Echchabi, and Aziz's (2015) critically reviewed recent literature of conventional and Islamic behavioral finance and made useful comparisons and conclusions on the nature of Islamic behavioral finance. They argued that studies in Islamic behavioral finance are primarily based on the intention to invest and the perception to some Islamic investment products, they are not attached to specific behavioral patterns and preferences and they are conducted in a conventional context. They asserted that an Islamic comprehensive framework is needed instead of a mere application of psychological theories that are not verified against the Islamic paradigm.

A recent paper of Adeyemi and Haron (2016) genuinely applied behavioral finance in Islamic banking and finance through studying the influence of religiosity and some behavioral biases on shaping the financial decision-making of Muslim investors. They argued that in order for Islamic banking and finance practitioners to achieve operational efficiency as well as equity and fairness, they should consider the religion-moderated cognitive biases that shape their banking, financing, and investing decision. Other than the tow aforementioned papers, there is a need for the establishment of genuine and authentic Islamic behavioral finance and financial therapy that starts with the human nature of Islam.

\subsubsection{Human Nature in Islam}

Qutb (1993) and S. Qutb, (2006) pointed out that there is no detailed psychological theory in Al-Quran, but there are various comprehensive information on the human nature that can be inspired to derive a comprehensive theory of human nature along with all-embracing guidance on how to deal with it. Alias (2012) further argued that Al-Quran outlines briefly, and sometimes in detail, major psychological topics. This indicates that Islamic view of human nature is both normative and descriptive and thus, Islamic behavioral finance and financial therapy should follow this approach. Izetbegović (2013) argued that Islam aims to create a man who is consistent with his spirit and body and to create a society where its laws and its economic and social institutions preserve this consistency. Thus, Islamic behavioral finance and Islamic financial therapy should start with central questions that forms the worldview about human nature, his existence, his substance, and his end.

In the economic context, some Muslim economists proposed Homo Islamicus as an alternative to the concept of "homoeconomicus". Homo Islamicus is defined as an altruistic agent who lives as a part of an idealized society that is embedded with Islamic values and commitment and is concerned about social justice and human-centered economic growth and development (Warde, 2000; Asutay, 2007; Farooq, 2011). Warde (2000) argued that Homo Islamicus is similar to homoecnomicus in terms thier normativity, which makes them largely irrealvant and should be replaced with descriptive models.

\subsubsection{Indigenizing/Islamizing Psychology}

After ignoring the role of religion, spirituality and values in psychology in general and psychotherapy, in particular, and considering them as taboos, recent researches, professional standards best practices emphasize and signify their role in positively influencing the client's psychological well-being and mental health (Badri, 2000, 2012; Hamdan, 2008; Haque, 2000; Razak, Mohamed, \& Mutiu, 2013; Waller, Trepka, Collerton, \& Hawkins, 2010). As faiths, values and spirituality play a considerable role in promoting psychological well-being and mental health, behavioral finance and financial therapy are essentially expected to consider these influencers. Badri $(1979,2012)$ further argued that as human behavior is based on the interaction between three components: the biological, psychological, and socio-cultural, it is undiscussable that Islam as a religion and a way of life has a great influence on the last two components.

Putting aside the scientific findings of psychology that are mostly accompanied with other pure and exact sciences such as biochemistry, neurology, physiology and genetics, Western psychology can be harmful without indigenization (Badri, 2012; Samsuddin, 2012). This is because some psychological knowledge comes from uncodified and intuitive experience, philosophy, pseudo-knowledge and art that lack a holistic general grand 
theory like other profound sciences (Deese, 1972; Badri, 2012).

The unethical "wholesale" exportation of social psychology knowledge, which is of highly questionable reliability and validity in the Western context, to the third world (Moghaddam \& Harre, 1995) and the mixed nature of Western psychology has led to the emergence of indigenous psychology. Sinha (1997) defines indigenous psychology as a continuous process of evaluation and revision of the philosophy and practice of psychology in accordance with the specific needs of a particular society and culture. Samsuddin (2012) pointed out that Islamization is an indigenization endeavor to analyze the incompatibility of some psychological philosophies and theories from the Islamic perspective and to produce an implementable and cross-cultural psychology that suite other than Western cultures.

Badri (2012) suggested three approaches in dealing with the modern Western psychology that consist of Islamization, acceptance and adaptation. Islamization is needed in the areas that is based on the inti-Islamic and quasi-religion secular humanism such as humanistic psychology, psychoanalysis and most of psychotherapy. Acceptance include all neutral and pure scientific psychology, which consist of scientific and exact theories such as psychophysics and statistical psychology. On the other hand, the adaptation is needed for the big neutral areas such as psychological testing that are applicable in Western context only and thus need to be changed to be more suitable to different Muslim cultures.

As financial therapy has many psychological approaches the Islamization depends on their underlying philosophies and concepts to determine what to be Islamized, what to be accepted and what to be adapted. In General, Badri (1996) compared Islamic and conventional psychotherapy and counselling by posing three major differences. First, Modern psychotherapy and counseling are based on an anti-religious materialistic philosophy. Second, they are non-judgmental and thus, reject "Good", "Evil" and religious moral responsibility. Third, they do not provide the client with an ideal role model. Consequently, this distinction is essential when developing Islamic financial therapy.

\subsection{Wealth Management}

\subsubsection{Essence}

Wealthy people are classified differently based on their total net worth. Some studies classify wealthy people from the top to the lower to: Ultra-High-Net Worth Individuals (UHNWIs), Very HNWIs, HNWIs, Wealthy and Affluent, while others reduce the classes to three: UHNWIs, HNWIs and mid-tier millionaires (Beaverstock, Hall, \& Wainwright, 2013). The net worth is generally quoted in terms of liquid assets it differs by financial institution and region, however, the most commonly quoted figure is one million U.S dollar in liquid financial assets (Investopedia, 2016).

Evensky, Haron, and Robinson (2011) described wealth management as comprehensive, customized and complex, which is aimed to tailor customized solutions to fulfill the unique financial needs of each client. Accordingly, they organized the process of wealth management to four interrelated general categories; client relationship, client profile, investment policy and portfolio management, monitoring, and market review which are depicted in Figure 1. Among the services that are provided to wealth management clients are investment management, asset allocation, tax-wise investing, personal financial planning, estate planning, technical acumen and risk management (Jennings, Horan, Reichenstein, \& Brunel, 2011).

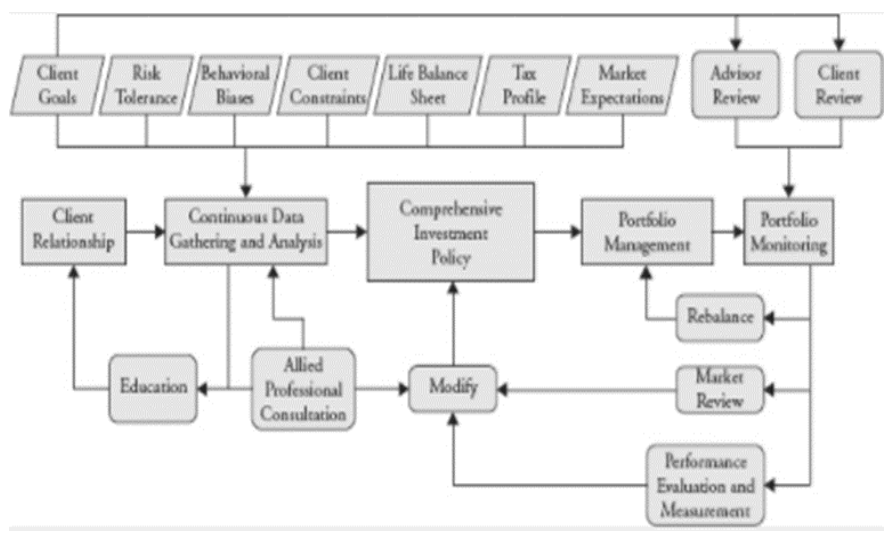

Figure 1. The wealth management process

Source: Evensky, Haron and Robinson (2011). 


\subsubsection{Trends}

Two major types of trends received a considerable attention due to their significance to the industry: demographic and technological trends. Some trends are affecting the nature and future of the advice itself such as the simultaneous increase of both standardization and personalization of advice and the demand for a comprehensive and holistic advice, for omnichannel delivery of advice, and for a new business model (Spellacy \& Patel, 2016). Fischer, Jonge, and Toepfer (2013) pointed out that wealth management must fundamentally transform from product-centric toward client-centric business models that is built on a real value added services and a tailored, comprehensive and highly customization advice. Similarly, Jackson and Stepanyan (2013) asserted on the client centricity and the emphasized the client's discovery and needs analysis.

The rise of the millennials (who were born after 1980 and reached adulthood with the turn into the $21^{\text {st }}$ century) and Generation X (who were born between 1968 and 1978) as the new clientele of wealth management received tremendous attention. Millennials followed by Generation X are the largest population groups in the world and occupy the biggest proportion of the workforce in many countries (Horan, 2015; Kobler, Hauber, \& Ernst, 2016; Robinson, 2016; Spellacy \& Patel, 2016). Having a great net wealth ranging from US\$19 to 24 trillion for millennials and -even greater net wealth of Gen X- makes them the future client of wealth management institutions (Ciompi \& Jacobs, 2016; Horan, 2015; Kobler et al., 2016).

Described as Re-wired Investors, millennials and Gen X are notably different from the previous generations in terms of their behaviors, thinking patterns, standards, expectations, values and preferences (Horan, 2015; Vincent et al., 2015; Ciompi \& Jacobs, 2016; Kobler et al., 2016; Robinson, 2016). Being more cautious and conservative toward financial matters, having low to medium financial knowledge, having negative perceptions towards financial advisors and preferring to be self-directed in investments are among the unique characteristics of these generations (Horan, 2015; Kobler et al., 2016).

HNW individuals is also classified differently by another demographic generation that is called Gen D and is based on a set of different characteristics. Accenture (2015) stated that they are well educated, highly digital, and currently utilize a financial advisor or wealth manager and consider the digital environment to be an essential part of their wealth managers' offerings. Thus, a deep understanding of these generations' needs and preferences is essential to succeed in such a competitive industry. Other demographic trends include the transfer of wealth from baby boomers to the Xers and millennials and the aging financial advisors who will pass their roles to these generations (Raffa, 2014; Vincent et al., 2015; Spellacy \& Patel, 2016).

Fintech innovations are also transforming the wealth management industry. Fintech usually refers the intersection between financial services and technology sectors, in which technology-focused start-ups attempting to leverage on digital technology and advanced analytics to unbundle financial services by targeting long-tail consumers. (Sironi, 2016; PWC, 2016). Wealth management is one of the least tech-literate sectors of financial sectors and its institutions are among the top disrupted financial services providers whose financial executives perceive Fintech firms as significant threats to their business (Capgemini, 2016; PWC, 2016).

Robo-advisors is among the biggest threats to traditional wealth management firms (Accenture, 2015b; Sironi, 2016). The low fees and the minimum amount to open an account broaden the target market to include almost all people with relatively low savings (Traff, 2016). However, the reliance on robo advisors negatively related to the complexity of financial needs and amount of wealth involved (Vincent et al., 2015; Sironi, 2016).

\subsubsection{Wealth Management and Behavioral Finance}

Downsizing the roles of wealth manager results in two primary roles, investment management and financial planning. Behavioral finance can have numerous applications on how to know the client better in order to help him/her make optimal decisions that lead to a greater satisfaction toward financial and financial needs and goals. Kahneman and Riepe (1998) argued that an effective financial advice must be guided by an adequate understanding of the cognitive and emotional weaknesses of the individual investor pertaining to investment decision-making.

Pompian and Longo's (2005) delineated some practical guidelines on how to better allocate a client's assets by considering his/her behavioral biases and when to moderate or adapt such biases. Similarly, Sahi, Arora, and Dhameja (2013) and Hens and Meier (2015) emphasized the importance of diagnosing, assessing and dealing with the psychological/ behavioral biases on individual investors' beliefs, attitudes and preferences toward their investment decision-making.

Beside behavioral biases and psychological factors, numerous researches were conducted to examine and study the various factors that influence the financial decision-making of individual investors (Pompian, 2016). This 
includes gender (Barber \& Odean 2001; Beckmann \& Menkhoff, 2008), culture (Statman, 2008a, 2015), religiosity (Baele, Farooq, \& Ongena, 2014; Kanagaretnam, Lobo, Wang, \& Whalen, 2015; Adeyemi \& Haron, 2016), personality types (Lin, 2011; Zaidi \& Tauni, 2012; Durand et al., 2013; Kübilay \& Bayrakdaroğlu, 2016; Pompian \& Longo, 2004) and temperament (Statman \& Wood, 2004).

Some other studies combines several factors that can infleunce the financial decision-making. For instance, Durand et al. (2013) examined several factors -using different dimensional indicators- that affect investment choices and outcomes including personality types, behavioral biases, preference for innovation, risk-taking propensity and psychological gender. Likewise, Lin (2011) and Zaidi and Tauni (2012) studied the effect of demographics such as age, gender, educational background, residential area and investment experience on the behavioral biases that affect the financial decisions. Borgers and Pownall (2014) and Statman (2004, 2008b), stated that client's preferences and values such as social status, social responsibility and fairness should also take place in financial advice.

A profound application of behavioral finance in wealth management that is considered as an integration between traditional and behavioral finance is Goal-based investing (GBI) (Nevins, 2004). GBI theoretically evolved when Shefrin and Statman (2000) developed the behavioral portfolio theory BPT that shifts form Markowitz's mean-variance theory. Nevins (2004) argued that a framework which aligns investment strategies and risk profiling techniques to goals, deliver superior outcomes than traditional framework, as it makes the asset allocation process and the whole financial advice more meaningful.

As a model of GBI, Chhabra (2005) proposed an ideal portfolio that protects the investor from three types of risks; poverty and anxiety (personal risk), maintaining living standard and social status (personal risk) and increasing wealth (market risk) or meeting aspirational goals (aspirational risk). Vincent et al. (2015), Welch (2015) and Sironi (2016) argued that the age of Fintech with its democratization, commoditization, disintermediation and digitalization requires a greater emphasis on highly personalized, highly customized and holistic advice, and GBI is a great step toward achieving that.

As an ultimate goal of financial advice, what individual client should sense and achieve is not the mere increase of returns, but rather " a greater degree of comfort with how assets are working to allow needs, wants, wishes, and dreams to be achieved, all the while avoiding night- mares, fears, concerns, and worries" (Brunel 2015, p. 10). Realizing the need for a wide scope of services, researchers are beginning to explore new methods of client discovery other than the current one (Belkora, 2015). Prarisse and Richman (2006) emphasized that what differentiate the financial advisors is asking in-depth questions that diagnose the deep financial needs, wants, hopes, dreams and feelings.

Statman and Wood (2004) suggested that risk tolerance questionnaires should be accompanied with temperament-based questionnaires that combine goals, hopes and fears along with risk and expected return, which can lead to promotion to both client's wealth and well-being. Statman and Pan (2012) suggested a new investor questionnaire that analyzes risk tolerance, overconfidence, maximization, regret, trust, and life-satisfaction. Nevins (2004) proposed separate risk tolerance questionnaires for separate financial goals rather than an overall risk tolerance for all investments. In widening client balance sheet, Wilcox (2005) proposed a client's life balance sheet that includes both implicit and explicit assets and liabilities, beside discretionary wealth while Pompian $(2009$, 2012b) developed the behavioral alpha (BA) to classify investors into four behavioral investor types or BITs.

In creating new client discovery methods, Belkora (2015) applied a patient discovery method "SLCT" in financial advisory and found it achieving an improved rate of insight into client needs goals, concerns, interests, priorities, increased advisory inquiry, client disclosure, and documentation of the client agenda. Comparably, Kinder and Galvan (2005) developed EVOKE; a methodology of client discovery that widens the scope of financial planning to be life planning.

\subsubsection{The Evolving Role of Financial Advisor/Wealth Manager}

The influence of psychology, brought by behavioral finance and financial therapy, changes the role of financial advisor from merely a portfolio manager and a financial planner to be in one part a psychologist (E. Baker, 2004; E. Baker et al., 2012; Davidow, 2015; Peterson, 2009; Towel et al., 2015). The financial advisor role is extended to be a financial physician, (Statman, 2002) a social worker (E. Baker et al., 2012), a choice architect (Towel et al., 2015), a life coach and planner (A. Jackson, Saffeel, \& Fitzpatrick, 2016; Kinder \& Galvan, 2005; Michael, Hartwell, \& Ho, 2015), a financial coach and financial therapist (Belkora, 2015). Significantly, the evolving role of financial advisor requires emotional intelligence and due consideration to the non-financial factors affecting client decision-making to build trusted relationship (Peterson, 2009; Weisinger, 2004). 


\subsection{Islamic Wealth Management}

\subsubsection{Underlying Philosophy and Concepts}

The Islamic worldview pertaining to Islamic wealth management is based on the principle that the Allah Almighty is the sole giver of the wealth and man is merely a trustee who must safeguard the trust to gain the His pleasure and to succeed in fulfilling his role as an obedient of Him (Shafii, Yusoff, \& Noh, 2013; Qaseem, 2016).

The Sharīah compliance represents the legalistic aspect of Islamic finance in which adherence to certain prohibitions are crucial for its validity. Such general prohibitions include Riba (usury), Gharar (ambiguity), Maysir (gambling) and other prohibited things such as intoxicant and pork. These prohibitions are operating in the domain of objectives such as justice, cooperation, mercy, integrity, avoidance of wealth concentration and responsibility.

The all-embracing and comprehensive Shariah guidance on wealth includes its accumulation, protection, growth, consumption, purification, and disposition/distribution (Ahmed, 2013; Othman \& Subramaniam, 2013; Qaseem, 2016; Tasdemir, Cobanoglu, \& Iqbal, 2016). Islam obliges Muslims to earn their livelihood that ensures a tranquil and honorable life for oneself and dependents through permissible means (Othman \& Subramaniam, 2013; Qaseem, 2016; Tasdemir et al., 2016). Farooq (2014) stressed on the positive-sum objectives of Islamic wealth management, as wealthy people should avoid highly skewed concentration of wealth and contribute to the welfare of society.

Protecting wealth derives its importance from the domain of protecting the five necessities in Islam: religion, life, intellect, wealth, and honor (Qaseem, 2016). Protecting wealth is assured by encouraging legitimate earning and by prohibiting certain acts and crimes (Tasdemir et al., 2016) such as indolence, laziness, extravagance, rubbery, and burglary (Othman \& Subramaniam, 2013; Qaseem, 2016; Tasdemir et al., 2016).

Islamic wealth management differs more distinctly from the conventional counterpart in the three stages of wealth: purification, consumption and distribution. Accumulating and protecting wealth must be attached to purification through obligatory Zakah and voluntary charity (Othman \& Subramaniam, 2013; Qaseem, 2016). Wealth consumption is the most critical area of Islamic wealth management that diverge greatly from the conventional once, yet it is the most neglected one (Shafii et al., 2013; Qaseem, 2016; Tasdemir et al., 2016).

For consumption, Islam obliges its followers to tread the middle way between niggard and wasteful extravagance, to spend their wealth in lawful activities, to give portion of their wealth to the needy and to the society through obligatory zakah (obligatory yearly payment to specified beneficiaries) and voluntary charity, and to prioritize their spending (Qaseem, 2016; Tasdemir et al., 2016). Islamic wealth distribution is mainly based on the unique laws of inheritance (Faraidh), beside wills, endowment (Waqf), trusts and other forms of lawful distribution.

\subsubsection{Islamic Wealth Management Industry}

Islamic wealth management industry accompanied with Islamic asset management is considered as a potential booster and promoter of the Islamic banking and finance (MIFC, 2016; Thomson Reuters, 2015). Edbiz Consulting (2016b) pointed out that the significant reliance on the conventional products and the weak presence of Islamic wealth management, the lack of interest in IFS by wealthy people and the lack of products for IWM are among the causes of the very weak presence of IWM.

Islamic wealth management has emerged as part of Islamic finance and thus, it broadly shares the features, underlying principles, advantages as well as limitations of Islamic finance (Farooq, 2014) including the dichotomy between Shariah objectives and practice (Ahmed, 2013). Ismail and Antonio (2012) and Sandwick (2011) argued that Islamic wealth management is not different from the traditional one, except for the distinctive criteria: the Shariah-compliance and purification through Zakah. Farooq (2014) highlighted that Islamic financial institutions including IWM is still prohibition-driven industry not socioeconomically driven. Chapra (1985) and El-Gamal (2007) asserted on the imperative of socio-economic justice and the inviolable goal of enhancing general social welfare.

In having multiple goals, Abozaid and Dusuki (2007), Ayub (2007) and Dusuki (2007) emphasized the notion of comprehensiveness of Shariah objectives that promote inner consciousness, fairness and justice accompanied with economic, social and political and financial goals that should balance between the self and social interests and between the individual, family, society and the state.

Asutay (2007) highlighted the divergence between Islamic economics whose objectives are social justice and human-centered economic growth and development, and the practices of Islamic banking and finance. The commercial necessity, the competition for profitability and the overriding concern of growth and innovation of 
Islamic finance are among the rudimentary reasons that lead to this dichotomy and divergence between the Islamic authentic economic goals and the Shariah compliance (Siddiqi, 2006; Ayub \& Paldi, 2015).

Islamic wealth management as a part of the Islamic economics should not focus only in fulfilling legal injections related to Islamic finance, but it should also take into account social justice and social welfare (Ahmed, 2013; Tasdemir et al., 2016). In promoting and boosting Islamic wealth management industry, (MIFC, 2016) suggested a few steps to take IWM to the new development phase including further development of existing services to allow for more customization and opportunity for returns enhancement, continuous development of advisors' wealth management skills and increasing public awareness of Islamic wealth management.

\section{Therortical Framework}

The overreliance on the investment side of wealth management becomes a major drawback of the industry as robo-advisors and other Fintech innovations are increasingly taking over its place. This gives further importance to the other aspects of wealth management that requires human interaction such as financial planning, client education and reinforcement of good financial behavior (Traff, 2016). Applying behavioral finance and financial therapy can promote human interaction that is concerned about the two categories of wealth management process organized by (Evensky et al., 2011), client relationship and client profiling.

Many wealthy clients put a notable consideration on factors other rate of return such as well-being, religious beliefs, personal values, family matters, social preferences, and other non-financial goals and needs that are shaped by many psychological, personal, and socio-cultural factors. The ability of correctly addressing the client's non-financial needs and goals is associated with a deep understanding of client's goals, beliefs, preferences, priorities, hopes, fears, dreams, behaviors and expectations along with backgrounds, personality, culture, demographics, interests and other variables that make every client unique in terms of both financial and non-financial needs.

As money is a fundamental aspect of sensing safety, security, quality of life, goals and aspirations (Britt, Klontz, \& Archuleta, 2015a), the ability of integrating financial and non-financial goals and needs enhances the meaningfulness of the client's wealth and financial goals, and would ultimately lead to client satisfaction and well-being. This broadened scope of wealth management services would greatly depend on the quality of the financial advisors who adopt more advanced discovery and profiling method and apply the findings of psychology driven disciplines such as behavioral finance and financial therapy in tailoring their advices. More importantly, the use and integration of psychology in financial advising encompasses almost every aspect of the advisor-client relationship, from risk tolerance questionnaires to financial planning, portfolio assets selection, and estate planning.

The growing interest of wealthy clients in including philanthropic giving in overall wealth planning (Heisman, 2015) indicates that Islamic wealth management as a value-based can utilize the functionality of this broadened scope to provide an extra feature to their services that account for broader objectives, namely social welfare through social responsible programs, initiatives, investments and actions that take into consideration spiritual, social, and economic factors. As there is a wide divergence between the ideality and reality of Islamic wealth management, it is essential to address the unspoken reasons of why Muslim wealthy people who own the overwhelming percentage of Muslim wealth barely contribute to their societies, and utilize the outcomes in creating new business models. Hence, the proposed model of this research focuses on exploring how inner factors (i.e. psychological factors) can have a great emphasis on tempting the HNWIs with their different levels of wealth to engage in promoting social welfare and enhance the quality of life of other individuals and households, beside fulfilling their own goals and enhancing their financial well-being.

\subsection{Underlying Definitions and Concepts}

Despite behavioral finance and financial therapy have been previously defined, there are still some several terms of the key variables of this model that need to be clarified. Firstly, Islamic wealth management is defined as the integrated financial services, which encompasses both investment management and personal financial planning, in accordance to Shariah principles, as a part of comprehensive advisory and management of a client's wealth (Edbiz Consulting, 2016a; Jennings et al., 2011). "Shariah principles" includes the legislative part as well as the entire Islamic value system. Secondly, social welfare includes "all programs and organizations in a country that are designed to prevent, alleviate, or contribute to the recognized social problems" (Zastrow, 2017, p. 3).

\subsection{Model Variables}

The following Figure 2 demonstrates that the application of effective client discovery and profiling methods and the application of behavioral finance and financial therapy, from an Islamic perspective, in Islamic wealth 
management (IWM) is a great potential step to promote social welfare. Applying an effective client discovery process that encompasses various financial and non-financial factors would assist the financial advisor to identify the emotional, cognitive and behavioral factors that can influence the client's financial decision-making, financial well-being and ultimately the quality of life.

This identification of the psychological factors are of two types; the identification of the behavioral biases that deviate the client from making optimal investment and identification of the undesirable and disordered money beliefs that influence his/her financial planning. As investment and financial planning are the essential components of wealth management, considering the psychological factors that influence them is crucial in order to provide a superior advice with high customization.

The financial advisor in the investment part of wealth management would apply behavioral finance to modify the irrational behavior caused by behavioral biases that lead to sub-optimal decisions. Financial therapy on the other hand is applied in the financial planning part of wealth management to modify undesirable and disordered beliefs about money that lead to irrational and sub-optimal decisions and consequently can affect the client's overall financial life. As Islam asserts on the dual nature of humans that consists of soul and body, any form of knowledge that ignores spirituality is rendered incompetent, inadequate and incapable in capturing the complete picture. Therfore, this duality is essential for both Islamic behavioral finance and financial therapy.

When applying the model, the financial advisor/wealth manager can step further to tempt the behaviorally and cognitively enlightened clients to apply their newly acquired cognitions to contribute to help them customize their contribution to the society in a way that is enhancing their financial life quality as well as benefiting society. Two factors beside the client discovery and profiling methld can contribute to the operationalization of the model. Firstly, the discretionary wealth that is left after fulfilling implicit and explicit liabilities, is the focus of the wealth manager/financial advisor to help the client to engage in socially responsible investments and projects that can have a notable impact on promoting social welfare. Secondly, to enhance the client experience and the credibility of the new socially-responsible offerings, user-friendly interfaces and sophisticated technologies such as big data analytics are expected to play this role.

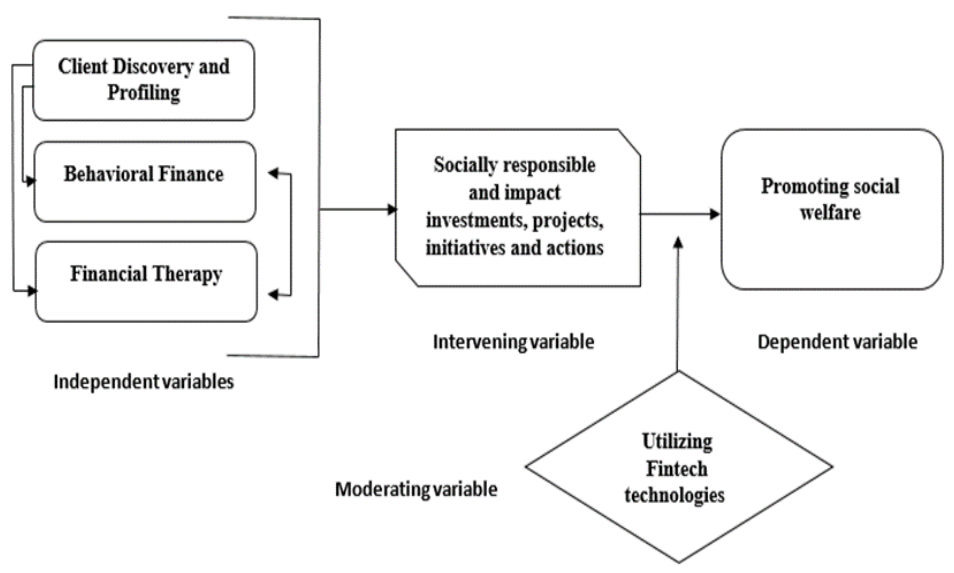

Figure 2. The proposed model

The model consists of two primary stages; the client discovery and profiling method that aims to explore the client's profile from a multi-dimensional aspect, and the financial therapy and behavioral de-biasing that aim to enforce healthy financial behaviors.

\subsection{Model Description}

\subsubsection{Client Discovery and Profiling}

A client-centric service is essentially based on a deep understanding of the client's goals, wants, needs, hopes, fears, dreams, interests and other factors affecting their decisions. This deep understanding is also essential to the fiduciary duty of financial advisor, emphasized by Islamic teachings and regulations. In other words, the more effective and comprehensive the client discovery, the higher the match between client's interest and goals and the financial plans provided by the wealth manager and financial advisor. In addition, building a profound, long-term and trusted relationship with the client significantly depends on the client discovery and profiling. 
This model blends several methods of client discovery and profiling which are Kinder and Galvan (2005) who proposed EVOKE and Belkora (2015) who recently applied SLCT method in financial advisory, accompanied with the Life balance sheet of Wilcox (2005) and psychotherapy assessments and diagnosis tests introduced by several authors that can be applied according to the different contexts and different client needs.

\section{EVOKE method}

EVOKE model broadens the financial planning to be a part of life planning. It employs a five-phase process using the acronym EVOKE: Exploration, Vision, Obstacles, Knowledge, and Execution.

\section{SLCT method}

Belkora (2015) applied SLCT a successfully-proven which stands for the interviewing tactics financial advisors use in the discovery session: Scribing, Laddering, Checking, and Triaging.

\section{Life Balance Sheet}

Wilcox (2005) argued that the balance sheet of a client is not limited to only explicit assets and liabilities, but also implicit assets and liabilities. Examples of implicit assets are the human capital and expected pension benefits, while implicit liabilities include funds that are aimed to maintain the lifestyle, college funds, mortgage and philanthropy. The excess capital or discretionary wealth that is left after fulfilling implicit and explicit liabilities is aimed to be grown and maintained above a zero level. Discretionary wealth is the zone that can be utilized by the wealth manager and financial advisor to help the client to engage in investments and projects that promote social welfare and thus, it should be managed properly. Integrating the four types of client discovery and profiling process would lead to more comprehensive picture of the client. The phases of the proposed integrated discovery method is sequenced as follows:

1) Exploring: this stage is formed from the first two stages of SLCT; scribing and laddering and the first phase of EVOKE; exploration. In this stage, open-ended questions are asked in order to draw what is in the top of the client's mind about the purpose and the expected outcomes and any other relevant information that would shape the advisor-client relationship.

2) Checking: the second phase of EVOKE; vision can be a considered as a part of the third phase of SLCT; checking and can be combined. The checklist contains some categorized information adapted from SLCT with some modifications and additions that expand its scope that are shown in the Appendix. This checklist is indicative and can be modified to suite the client's profile.

3) Detecting: this stage is newly added to the process to include psychological measures, scales and assessments pertaining to financial behavior and money beliefs. Conducting psychological and behavioral assessments and diagnostic tests to determine the susceptibility of behavioral biases, and undesirable and unhealthy beliefs that may deviate the client form achieving the plan. Such assessments are of three types:

i) Money beliefs inventories

Examples: Klontz Money Script Inventory (B. Klontz, Britt, Mentzer, \& Klontz, 2011) and Klontz Money Behavior Inventory (T. Klontz, Britt, Archuleta, \& Klontz, 2012)

ii) Financial behavior scales

Examples: Behavioral Investor Types (BITs) (Micheal M. Pompian, 2009), the Responsible Financial Behavior Scale (Perry \& Morris, 2005) and the Financial Behavior Scale (Garman, Kim, Cratzer, Brunson, \& Joo, 1999).

iii) Behavioral biases diagnostic tests

Examples: behavioral biases diagnostic tests presented throughout (Micheal M. Pompian, 2012b) can be adopted and expanded further.

Other assessments have also proven their applicability. Temperament-based questionnaires for financial advisors of Statman and Wood (2004), assessments of risk tolerance and other investor propensities such as regret, overconfidence and maximization of Statman \& Pan (2012), personality traits indicators such as Big Five Personality Traits and the Myers-Briggs Type Indicator (MBTI) have also been usable in financial advisory. Wealth manager with assistance from experts from financial planning, psychology and mental health should carefully select appropriate tools that suite every clients. More importantly, the wealth should also adapt such assessments to suite the culture and context in which he is operating.

4) Positioning: this stage is merely financial as the wealth manager/financial advisor prepares the life balance sheet adopted form Wilcox (2005) to effectively address the client's financial position. 
5) Identifying: identifying the internal and external limitations, restrictions and obstacles of the prospected plan, which is borrowed from, EVOKE method.

6) Documenting: producing a report that contains all information from the previous phases to be stored and processed by an analytical software, for reference and analysis which is adapted from SLCT method with the addition of the processing the data into a software.

The financial advisor would add his expertise to prepare the plan for the client that will end with an expanded investment policy statement. An important issue regarding the quality of the financial advisor is that he/she should be cognizant and well aware of the important conditions of the country the context where he/she is operating. This includes the political, economic, social, socioeconomic, demographic, geopolitical and other conditions that can not be obtained by only financial expertise, yet it can have indirect influence on the plan. Blending the information obtained from the discovery interview with financial expertise and general knowledge of the above-mentioned conditions would lead to a very insightful, excellent and breakthrough advice.

\subsubsection{Behavioral De-Biasing and Financial Therapy}

Islamic and conventional behavioral finance and financial therapy aim to determine the factors that deviate the investor/client from making optimal financial decisions. Thus, a rudimentary topic to highlight is the Islamic perspective of optimal decisions. For traditional finance, the optimal decisions are merely based on the right relationship between risk and return measured by the client's risk tolerance. On the other hand, for conventional behavioral finance, the optimal decision is that help attain the financial goals while simultaneously providing enough psychological security for the client to sleep at night (Pompian, 2012b). From an Islamic perceptive, the optimality of decisions for Muslim investors is the same as the conventional counterpart, however it adds to it the spiritual factor that can be briefly highlighted in the following points.

First, the financial goals should be viewed within its alignment to the Shariah principles. Second, the ultimate objective of making optimal financial decisions is to preserve the five necessities of Shariah; life, religion, intellect, linage and wealth. Third, client's financial goals should be viewed within the hierarchy of needs that includes essential, necessary and complementary needs. Fourth, financial goals should be aligned with the prioritization of beneficiaries. Fulfilling own, family and parents needs comes at the top, followed by the relatives in need, other people in need, and then the public at large.

\section{Cognitive psychology and CBT approach}

Behavioral finance and many of modern financial therapies are based on cognitive psychology; one of the major psychological schools of thought (Pompian, 2012). Cognitive psychology school provides more realistic model of human internal cognitive activities than other major schools such as the behaviorist and the psychoanalyst (Badri, 2000). It is based on the notion that the internal cognitive/thinking process (conscious or unconscious) directs every intentional and observable action/behavior of human (Badri, 2000; Glassman \& Hadad, 2009). In other words, our previous conceptualizations, emotions and experiences shape our current and future actions, ideas, behaviors and feelings. Thus, the role of cognitive-behavioral psychotherapy comes to identify and change thinking process that is uniquely influenced by these factors and can lead to certain sub-optimal financial decisions.

Cognitive-Behavioral Therapy (CBT) is one of the most prominent, empirically-supported and evidence-based psychotherapy approach that is effective for a variety of psychological conditions and one of the most widely used models for adapting to religious orientations (Badri, 2000; Beshai, Clark, \& Dobson, 2013; Hamdan, 2008; Haque, Khan, Keshavarzi, \& Rothman, 2016; Husain \& Hodge, 2016). These characteristics along with the wide presence in the financial therapy makes CBT a perfect approach for Islamic behavioral finance and financial therapy.

The CBT model can assist in identifying and understanding the perpetual interactions between the patterns thoughts, feelings and behaviors that are perceived undesirable, in order to restructure it and replace it with desirable alternatives (Ford et al., 2011). Beshai et al. (2013) highlighted that three essential propositions that forms the CBT approach include; (1) thinking and cognitions affect behavior; (2) cognitive activity is accessible and is amenable to change; and (3) desired behavioral change may follow from changes in thinking. This summrizes the very basic notion of CBT.

Dobson (2009) organized the interventions and procedures used in CBT to three categories: cognitive restructuring, coping skills building and problem solving. Cognitive restructuring, the core of the CBT, begins with the identification and evaluation of the automatic thoughts and core beliefs that lead to dysfunctional behaviors, followed by modifying these thoughts by challenging and questioning them and replacing them with 
positive thoughts which ultimately lead to desirable and healthy behaviors (Hamdan, 2008; Mccoy et al., 2013).

\section{The Islamic psychospiritual approach}

Religion and spirituality can have a great impact on the thinking process that lead to certain undesirable behaviors. This spiritual dimension of Islamic behavioral finance and financial therapy represents their uniqueness and powerfulness. The power of the spiritual dimension comes from its ability to alter any behavior enhancing or reducing it- caused by any money belief. This is due to the complete submission that the believer should adhere to the Godly teachings and guidance.

Cognitive psychology and CBT approach ignore the spiritual factor as a powerful cognitive force (Badri, 2000; Dzulkifli, 2012). The approach of cognitive psychology as CBT from an Islamic perspective is essentially psychospiritual in which the use of religious and spiritual concepts is an inseparable part of the therapy and in which spiritual and the physical spheres are intertwined. This psychospiritual approach has been used long time ago by Muslim doctors and scholars who used a mixture of behavioral gradual training with a spiritual and Islamic cognitive approach that is found very effective in modern days for Muslim clients (Badri, 1996, 2012; Dzulkifli, 2012; Razak et al., 2013; Waller et al., 2010).

The close similarity of this psychospiritual approach to the modern highly creditable CBT indicates its viability, effectiveness and applicability to not only Muslims, but also people of other faiths. In this sense, Hamdan (2008) proposed an Islamically-based cognitive restructuring that revolves around significant cognitions from the Islamic precepts, which can be very effective when incorporated into the counseling process with Muslim clients. Husain and Hodge (2016) argued that the Islamically modified CBT can lead spiritually motivated Muslims to faster recovery, enhanced treatment compliance, lower levels of relapse, and reduced treatment disparities.

Modifying undesirable financial behaviors according to cognitive-behavioral therapy is based on discovering how the investor/client is thinking, feeling and behaving. This discovery process should be of two kinds; discovering disordered/undesirable money beliefs and discovering behavioral biases. Money beliefs are more holistic and related to the financial planning aspect of wealth management, while behavioral biases is more specific and related to the investment management aspect of wealth management.

Money beliefs are understood as what we think about money in general and thus, they are considered as the drivers of behavioral biases or unhealthy financial behaviors. The correct way of de-biasing is to identify the client's money beliefs first and then the associated behavioral biases in order to modify them and guide the client to exploit them in order to achieve his/her financial, aspirational and life goals. The Al-Quran and Sunnah (prophetic traditions) contain numerous verses and scripts that explain some general money belief such as the beautification of wealth for people and that people have an immense love for it (Al-Quran 3:14; 89:20) and that wealth never be enough for human (Al-Bukhari, no. 6436).

In the context of social welfare, money beliefs that could prevent the client from engaging in social welfare could be the excessive desire for accumulating wealth, debasing the impact of philanthropy, mistrust of socially responsible investments and forgetting the temporal reality of this world and the supposed utmost focus on the hereafter. Other disordered beliefs differ from client to client depending on their experience, backgrounds and other factors.

Behavioral biases discussed in the conventional behavioral finance are considered as means to filter the information and make sense and due to their universality; many behavioral biases are applicable to Islamic behavioral finance. For instance, The Prospect Theory that underlies conventional behavioral finance can be very useful for Islamic behavioral finance so as other universal cognitive biases including cognitive dissonance; mental accounting; regret aversion; and overconfidence; (Kahneman \& Riepe, 1998; Micheal M. Pompian, 2012b; Shiller, 1998).

Behavioral biases need an adaptation for Muslims investors to suite their culture and contexts. The adaptation of the tools used to identify and treat biases is necessary as they were developed to suite the Western culture. Islamic behavioral finance can contribute by exploring new behavioral biases that can be of three types. First, universal cognitive biases that can be explored the same way existing biases were explored. Second, universal cognitive biases that are derived from the Islamic primary sources; Al-Quran and the Sunnah (prophetic traditions) and secondary resources; the classical works of Muslim scholars. Third, behavioral biases that exist in different Muslim cultures and are only applicable in their contexts.

In the context of promoting social welfare, wealthy clients can have pre-judgmental thoughts or behavioral biases that prevent them from engaging in the socially oriented investments and projects. Such opinions and thinking patterns are condemned in the Al-Quran when it mentions the behavior of those who follow their fathers 
in their misguidance without verification (Al-Quran 2:170; 43:20). Relating this to behavioral finance, this kind of behavioral bias is related to conservatism bias; and status quo bias; (Pompian, 2012b). Accompanying that with the Quranic verse that calls people to ascertain the truth of what they have been told (48:6), the client can modify core thoughts about contributing to social welfare.

As philanthropy is a core element in promoting social welfare, the wealth manager as a financial advisor and therapist should make an awareness of some related behaviors that are condemned in Al-Quran. Examples of such behaviors are the spending from inferior goods that are not loved by the giver himself (Al-Quran 2:276; 3:92), being niggard, stingy and miser in philanthropic spending (Al-Quran 4: 37; 9:34 \&75; 47: 38; 57:24; 17:100), following spending with reminder and injury (Al-Quran 2: 262;3:38) and not giving and aiding relatives and needy who are being hatred by the giver (Al-Quran 24:22).

Before and after engaging in investments and projects that contribute to social welfare, the client may be fearful of taking such decisions that can prove their sub-optimality, which is termed as regret aversion bias in behavioral finance terminology. A part of modifying such biases can be by changing the thoughts about the optimality of decision and that it is possible to dislike a thing that is in fact good for the person and love thing that is actually bad for him (Al-Quran 2:216), and that no one ever can benefit or harm him unless it is written by Allah Almighty (Al-Tirmithi: no. 2516). Changing such automatic or core thoughts of regret could entirely shift one's behavior from undesirable to desirable. For instance, if the investor realizes that the ultimate knowledge, power, and ability belong to the Allah Almighty, then, one should not underestimate the feasibility and impacts of socially-responsible investments and projects that promote social welfare. The aforementioned biases are a few examples of the unique Islamic behavioral/spiritual biases that can be extracted from the Islamic resources, other examples can be also numerously found.

\subsubsection{Fintech Role in Operationalizing the Model}

The uses of advanced and sophisticated analytics in wealth management are numerous and include asset allocation, identifying and quantifying risk and others. Two types of Fintech technologies can be used. First, analytics that integrate behavioral finance and financial therapy findings in an operating business model to assist wealth managers in order to provide more holistic and personalized advice that interconnects financial goals to life goals.

Currently, Essentia Analytics (2017) is integrating investment, technology and behavioral science in a behavioral software to assist fund and wealth manager to make optimal and breakthrough decisions. Similarly, IBM (2017) and IBM Watson (2017) are providing the Goal-based Investing and Client Insight for Wealth Management, which are based on big data analytics that are utilized to assist wealth managers in providing more personalized advanced and insightful advice.

The second type of Fintech innovations is the platforms and applications that enable the client to track, monitor and interact with socially and impact investments and philanthropic projects and initiatives. Through such interfaces and platforms, the client can assure that his/her contribution to the social welfare through investment and charity are achieved and becomes fruitful.

\section{Conculsions}

Integrating finance with other social sciences such as psychology has proved its importance and usefulness. Behavioral finance and financial therapy are major outcomes of such integration that attempt to humanize and widen the scope of finance by looking at the financial phenomena from a multi-dimensional perspective. The Islamic perspective of behavioral finance and financial therapy revolves around three approaches that depends on the type of knowledge; acceptance, adaptation and Islamization, besides, including the spiritual factor to the presented concepts.

The application of psychology in wealth management has gained a wide acceptance that takes psychological factors such as behavioral biases that affect the financial decision-making into due consideration. Islamic wealth management is exposed to most of the trends of the conventional wealth management including the potentially of applying findings of the psychological-driven disciplines. However, as it is a value-based, it should utilize these findings in fulfilling its ultimate objective of promoting social welfare.

By utilizing the immense information and insights gained from the client discovery process and application of behavioral finance and financial therapy blended with the advanced analytics and user-friendly interfaces and platforms, Islamic wealth management could step further in fulfilling its objective of social welfare. Developing and implementing such integrated models require broadened business strategies that are founded on harnessing the company resources to achieve high level of customization. 
There is a vast need to model psychology in all sub-industries of Islamic banking and finance. Modeling psychology begins with the awareness of its importance among all stakeholders from scholars and academicians to boards of directors, managers and practitioners. This should be followed by adopting the best practices in the conventional financial services industry where many giant and influential corporations have realized the importance of psychology and thus, embedding it in their business models. This should be backed by building an organizational culture that admires the benefits of psychology in gaining a competitive advantage. This is beside developing training programs for the company employees including managers, wealth managers and financial advisors and hiring or contracting with psychologists, technologists and other experts whose advices would tackle non-financial issues within a framework that represents the Islamic values and doctrines, in order to form a well-rounded business model.

Creating truly-Islamic perfectives on psychology, behavioral finance, financial therapy and other related disciplines by joint bodies that consist of Muslim thinkers, psychologists, economists, financial experts and other social scientists is necessary to develop a well-rounded Islamic perceptive that has its unique applicable identity. The megatrends of wealth management industry including demographic and technological trends should also be highly utltized by Islamic wealth managemtn practtiotners. This would lead to an optimal long-term relationship that is based on trust, loyalty and satisfaction from the client's side and professionalism, high performance and commitment from the financial advisor's side.

\section{References}

Abozaid, A., \& Dusuki, A. W. (2007). The Challenges of Realizing Maqasid al-Shari ah in Islamic Banking and Finance. In IIUM International Conference on Islamic Banking and Finance: "Research and Development: The Bridge between Ideals and Realities" (pp. 1-27).

Accenture. (2015a). Generation D Europe: ResearchServing the High Net Worth Investor. Accenture.

Accenture. (2015b). The Rise of Robo-Advice: Changing the Concept of Wealth Management. Accenture.

Adeyemi, A. A., \& Haron, R. (2016). The Behavioral Biases of Muslims in Islamic Banking and Finance: A Second-Order Self-Reported Religiosity Measurement Invariance. Journal of Islamic Thought and Civilization, (Special Issue: Islamic Banking and Finance), 87-114.

Ahmed, H. (2013). Islamic Wealth Management: Goals and Instruments. $Q$ Report, $26-30$.

Al-Bukhari, M. I. I. (2002). Sahih Al-Bukhari (Al-Bulhari Collection of Authentic Profitic Traditions) (Scholarly Committee, Ed.) (1st ed.). Damscus: Dar Ibn Katheer.

Alias, A. (2012). Teaching Human Nature in Psychology Courses. In N. M. Noor (Ed.), Psychology from an Islamic Perspective: A Guide to Teaching and Learning (3rd ed., pp. 77-112). Kuala Lumpur: IIUM Press.

Al-Masiri, A. (2006). Difaa' An' Al-Ensan (Defending The Human) (2nd ed.). Cairo: Dar Al-Shurooq

Al-Quran Al-Kareem (English Translation of the Noble Quran). (1996). Al-Madinah Al-Munawwarah: King Fahd Complex For Printing The Glorious Quran.

Al-Tirmithi, M. I. I. (1975). Sunan Al-Tirmithi (Al-Tirmithi Collection of Profitic Traditions) (A. M. Shaker, M. F. Abdul-Baqi, \& I. Atwah, Eds.) (2nd ed.). Mustafa Al-Babai Al-Halabi Publishing.

Archuleta, K. L., Burr, E. A., Dale, A. K., Canale, A., Danford, D., Rasure, E., ... Horwitz, E. (2012). What is financial therapy? Discovering mechanisms and aspects of an emerging field. Journal of Financial Therapy, 3(2), 57-78. https://doi.org/10.4148/jft.v3i2.1807

Asutay, M. (2007). Conceptulaization of the second best Solution in Overcoming the Social Failure of Islamic Banking and Finance : Examining The Overpowering Of HOMOISLAMICUS by HOMOECONOMICUS. IIUM Journal of Economics and Management, 15(2), 167-195.

Ayub, M. (2007). Understanding Islamic Finance. Understanding Islamic Finance. West Sussex, England: Wiley Finance \& Sons. Retrieved from http://books.google.com/books?id=-3eZcL_kAkMC

Ayub, M., \& Paldi, C. (2015). Dichotomy between Sharī ' ah Compliance and the Economic Goals of Islamic Finance Institutions. Journal of Islamic Business and Management, 5(2), 69-98. https://doi.org/10.15341/jbe(2155-7950)/02.07.2016/017

Badri, M. B. (1979). The Dilemma of Muslim Psychologists (1st ed.). London: MWH London Publishers.

Badri, M. B. (1996). Counseling and Psychotherapy from an Islamic Perspective. Al--Shajarah, Journal of ISTAC, 1, 159-190. 
Badri, M. B. (2000). Contemplation: An Islamic Psychospiritual Study (1st ed.). Herndon, USA: The International Institute of Islamic Thought.

Badri, M. B. (2012). The Islamisation of Psychology: Its "Why". its "What", its "How" and its "Who." In N. M. Noor (Ed.), Psychology from an Islamic Perspective: A Guide to Teaching and Learning (3rd ed., pp. 13-41). Kuala Lumpur: IIUM Press.

Baele, L., Farooq, M., \& Ongena, S. (2014). Of Religion and Redemption: Evidence from Default on Islamic $\begin{array}{lllll}\text { Loans. Journal of Banking \& } & \text { Finance, 44(January), }\end{array}$ https://doi.org/10.1016/j.jbankfin.2014.03.005

Baker, E. (2004). Irrational Exuberance and Behavioral Finance: A Conversation with Robert Shiller about Integrating Investing and Social Sciences. The Journal of Investment Consulting Consulting, 7(1).

Baker, E., Statman, M., Towel, M., Anson, M., \& Gerber, G. (2012). The Human Side of Decision Making: Thinking Things Through with Daniel Kahneman, 13(1), 5-14.

Baker, M., Ruback, R. S., \& Wurgler, J. (2004). Behavioral corporate finance: A survey. Handbook in Corporate Finance: Empirical Corporate Finance, 1-63. https://doi.org/10.2139/ssrn.602902

Barber, B. M., \& Odean, T. (2001). Boys will be boys: Gender, overconfidence, and common stock investment. Quarterly Journal of Economics, 116(1), 261-292. https://doi.org/10.1162/003355301556400

Barberis, N., \& Thaler, R. (2003). A survey of behavioral finance. Handbook of the Economic of Finance, 1052-1121. https://doi.org/10.2139/ssrn.327880

Beaverstock, J. V, Hall, S., \& Wainwright, T. (2013). Servicing the Super-Rich : New Financial Elites and the Rise of the Private Wealth Management Retail Ecology. Regional Studies, 47(6), 834-849. https://doi.org/10.1080/00343404.2011.587795

Beckmann, D., \& Menkhoff, L. (2008). Will Women be Women? Analysing the Gender Differences among Financial Experts. Discussion paper No. 391 (Vol. 61). https://doi.org/10.1111/j.1467-6435.2008.00406.x

Belkora, J. (2015). Evaluating Client Discovery Interviews at a Financial Advisory Firm. The Journal of Wealth Management, 18(1), 9-23.

Beshai, S., Clark, C. M., \& Dobson, K. S. (2013). Conceptual and Pragmatic Considerations in the Use of Cognitive-Behavioral Therapy with Muslim Clients. Cognitive Therapy and Research, 37(1), 197-206. https://doi.org/10.1007/s10608-012-9450-y

Borgers, A. C. T., \& Pownall, R. A. J. (2014). Attitudes towards socially and environmentally responsible investment. Journal of Behavioral and Experimental Finance, 1, 27-44. https://doi.org/10.1016/j.jbef.2014.01.005

Britt, S. L., Klontz, B. K., \& Archuleta, K. L. (2015a). Financial Therapy: Establishing an Emerging Field. In B. T. Klontz, K. L. Archuleta, \& S. L. Britt (Eds.), Financial Therapy: Theory, Research and Practice (pp. 3-13). New York: Springer.

Britt, S. L., Klontz, B. T., \& Archuleta, K. L. (Eds.). (2015b). Financial Therapy: Theory, Research and Practice. Springer.

Brunel, J. L. P. (2015). Does Goals-Based Investing Help Achieve Better Investor Outcomes? Investments and Wealth Monitor, (Nov/Dec), 7-10.

Bruni, L., \& Sugden, R. (2007). the Road Not Taken : How Psychology Was Removed From Economics, and How It Might Be Brought Back. The Economic Journal, 117(January), 146-173.

Calnitsky, D., \& Dupuy-spencer, A. (2013). The Economic Consequences of Homoeconomicus : Neoclassical Economic Theory and the Fallacy of Market optimality. The Journal of Philosophical Economics, VI(2), $2-26$.

Capgemini World FinTech Report 2017. (2016). World FinTech Report 2017. Capgemini Financial Services.

Chapra, M. U. (1985). Towards a Just Monetary System. Leicester: The Islamic Foundation. Retrieved from http://ierc.sbu.ac.ir/

Chhabra, A. B. (2005). Beyond Markowitz: A Comprehensive Wealth Allocation Framework for Individual Investors. The Journal of Wealth Management, 7(4), 8-34.

Ciompi, C., \& Jacobs, J. (2016). Investable Assets of Tomorrow Getting to Know Gen-X and Millennial 
Investors. Investments and Wealth Monitor, (Nov/Dec), 40-43.

Credit Suisse. (2016). Global Wealth Report. Zurich, Switzerland.

Davidow, A. B. (2015). BEHAVIORAL FINANCE A Discussion with Nicholas C . Barberis , PhD. Investments and Wealth Monitor, Nov/Dec, 38--40.

De Bondt, W., Muradoglu, G., Shefrin, H., \& Staikouras, S. K. (2008). Behavioral finance: Quo vadis? Journal of Applied Finance, $18(2), \quad 27 . \quad$ Retrieved from http://138.38.0.49/management/news_events/events/behavioural-finance-economics-workshop/pdf/Gulnur.p df

Deese, J. (1972). Psychology as Science and Art. New York: Harcourt Brace Jovanovich.

Delgadillo, L. M., \& Britt, S. L. (2015). Financial Coaching and Financial Therapy: Differences and Boundaries. Family and Consumer Sciences Research Journal, 44(1), 63-72. https://doi.org/10.1111/fcsr.12127

Dobson, K. S. (2009). Handbook of Cognitive-Behavioral Therapies (3rd ed.).

Durand, R. B., Newby, R., Peggs, L., \& Siekierka, M. (2013). Personality. Journal of Behavioral Finance, 14(2), 116-133. https://doi.org/10.1080/15427560.2013.791294

Dusuki, A. W. (2007). The Ideal of Islamic Banking: A Survey of Stakeholders' Perceptions. Review of Islamic Economics, 11(Special Issue), 29-52. https://doi.org/10.1108/17538390810880982

Dzulkifli, M. A. (2012). Cognitive Psychology. In N. M. Noor (Ed.), Psychology from an Islamic Perspective: A Guide to Teaching and Learning (3rd ed., pp. 165-175). Kuala Lumpur: IIUM Press.

Edbiz Consulting. (2016a). Islamic Wealth Management in a Global Context. Islamic Wealth Management Report, 14-25.

Edbiz Consulting. (2016b). Knowledge, Attitude and Practices: A global survey on knowledge of Islamic wealth management amongst individuals and their attitudes towards it - demand side analysis - and practices of Islamic wealth management - supply side perspectives. Islamic Wealth Management Report, 82-93.

El-Gamal, M. A. (2007). Incoherence of Contract-Based Islamic Financial Jurisprudence in the Age of Financial Engineering. Wisconsin International Law Journal, 25(May), 1-15.

Essentia Analytics. (2017). Essentia Analytics Behavioral Software of Wealth Management. Retrieved March 15, 2017, from http://www.essentia-analytics.com/

Evensky, H., Haron, S. M., \& Robinson, T. R. (2011). The New Wealth Management: The Financial Advisor's Guide To Managing and Investing Client Assets. New Jersey: CFA Institute Publications.

Fama, E. (1970). Efficient Captial Markets: A Review of Theory and Empirical Work. The Journal of Finance, 25(2), 383-417. https://doi.org/10.1111/j.1540-6261.1970.tb00518.x

Farooq, M. O. (2011). Self-Interest, Homo Islamicus and Some Behavioral Assumptions in Islamic Economics and Finance. International Journal of Excellence in Islamic Banking and Finance, 1(1), 52-79. Retrieved from http://papers.ssrn.com/abstract=1740729\%5Cnhttp://papers.ssrn.com/sol3/papers.cfm?abstract_id=1740729

Farooq, M. O. (2014). Islamic Wealth Management and the Pursuit of Positive-Sum Solutions. Islamic Economic Studies, 22(2), 99-124.

Financial Therapy Association. (2015). What is financial therapy?

Fischer, R., Jonge, M. de, \& Toepfer, O. (2013). Wealth Management in New Realities: From defense to offense: How to realign business models for opportunities resulting from structural change.

Ford, M. R., Baptist, J. A., \& Archuleta, K. L. (2011). A Theoretical Approach to Financial Therapy: The Development of the Ford Financial Empowerment Model. Journal of Financial Therapy, 2(2), 20-40. https://doi.org/10.4148/jft.v2i2.1447

Garman, E. T., Kim, J., Cratzer, C. Y., Brunson, J. H., \& Joo, S. (1999). Workplace financial education improves personal financial wellness. Journal of Financial Counselling and Planning, 10(1), 81.

Glassman, W. E., \& Hadad, M. (2009). Approaches to Psychology (5th ed.). UK: Open University Press/McGraw-Hill Education.

Grable, J. E., \& Archuleta, K. L. (2011). The Future of Financial Planning and Counseling: An Introduction to Financial Therapy. In J. E. Grable, K. L. Archuleta, \& R. R. Nazarinia (Eds.), Financial Planning and 
Counseling Scales (pp. 33-59). New York: Springer.

Grable, J. E., Archuleta, K. L., \& Nazarinia, R. R. (Eds.). (2011). Financial Planning and Counseling Scales. New York: Springer.

Grable, J., McGill, S., \& Britt, S. (2010). The Financial Therapy Association: A Brief History. Journal of Financial Therapy, 1(1), 1-6. https://doi.org/10.4148/jft.v1i1.235

Hamdan, A. (2008). Cognitive Restructuring: An Islamic Perspective. Journal of Muslim Mental Health, 3(1), 99-116. https://doi.org/10.1080/15564900802035268

Haque, A. (2000). Psychology and religion: Two approaches to positive mental health. Intellectual Discourse, 8(1), 81-94. Retrieved from http://www.iium.edu.my/intdiscourse/index.php/islam/article/view/483

Haque, A., Khan, F., Keshavarzi, H., \& Rothman, A. E. (2016). Integrating Islamic Traditions in Modern Psychology: Research Trends in Last Ten Years. Journal of Muslim Mental Health, 10(1), 75-100. https://doi.org/http://dx.doi.org/10.3998/jmmh.10381607.0010.107

Heisman, E. (2015). Current Trends in Philanthropy. Investments and Wealth Monitor, Nov/Dec, 29-32. https://doi.org/10.2307/2785453

Hens, T., \& Meier, A. (2015). Behavioral Finance and the Psychology of Investing. USA.

Horan, S. M. (2015). The future of wealth management : Unpicking where the puck is going. CFA Instittute, 1-4.

Husain, A., \& Hodge, D. R. (2016). Islamically modified cognitive behavioral therapy: Enhancing outcomes by increasing the cultural congruence of cognitive behavioral therapy self-statements. International Social Work, 59(3, SI), 393-405. https://doi.org/10.1177/0020872816629193

IBM Watson. (2017). Client Insight for Wealth Management (Software). Retrieved February 7, 2017, from https://www.ibm.com/my-en/marketplace/client-insight-for-wealth-management

IBM. (2017). Goal-based Investing Software. Retrieved February 7, 2017, from http://www.ibmbigdatahub.com/infographic/goal-based-investing-wealth-management

Investopedia. (2016). High Net Worth Individual- HNWI.

Ismail, N., \& Antonio, M. S. (2012). The Islamic Wealth Management: An Analysis From IBN SīNĀ's Perspective. Journal of Islamic Thought and Civilization, 2(1), 19-36.

Izetbegović, A. (2013). Al-Islam Bayn As-sarq Wa Al-gharb (3rd ed.). Cairo, Egypt: Dar Al-Shurooq.

Jackson, A., Saffeel, D. P., \& Fitzpatrick, B. D. (2016). The Evolving Financial Services Industry : The Financial Advisory Role Today and in the Future. The Journal of Business Inquiry, 15(1), 17-32.

Jackson, N., \& Stepanyan, Y. (2013). Wealth Management Transformation. CAPCO.

Jennings, W. W., Horan, S. M., Reichenstein, W., \& Brunel, J. L. P. (2011). Perspectives From the Literature of Private Wealth Management. The Journal of Wealth Management, 14(1), 8-40. https://doi.org/10.1080/13562517.2010.515024

Johnson, R. R., \& Horan, S. M. (2013). Human Capital and Behavioral Biases: Why Investors Don't Diversify Enough. The Journal of Wealth Management, 16(1), 9-21. https://doi.org/10.3905/jwm.2013.16.1.009

Kahneman, D., \& Riepe, M. W. (1998). Aspects of Investor Psychology: Beliefs, Preferences, and Biases advisors should know about. The Journal of Portfolio Management, 24(4), 52-65. Retrieved from papers2://publication/uuid/B2D0C603-F0D1-4F95-AE72-07FBD632E7AD

Kahneman, D., \& Tversky, A. (1979). Prospect Theory: An Anlaysis of Decision Under Risk. Econometrica, 47(2), 263-292.

Kanagaretnam, K., Lobo, G. J., Wang, C., \& Whalen, D. J. (2015). Religiosity and risk-taking in international $\begin{array}{llll}\text { banking. Journal of Behavioral and Experimental Finance, } 7, & 42-59 .\end{array}$ https://doi.org/10.1016/j.jbef.2015.07.004

Kinder, G., \& Galvan, S. (2005). EVOKE ${ }^{\mathrm{TM}}$ : A Life Planning Methodology for the Coming Revolution in Client Relationships. Journal of Financial Planning, 405, 1-9.

Klontz, B. T., Britt, S. L., \& Archuleta, K. L. (2015). Theories, Models, and Integration in Financial Therapy. In Financial Therapy: Theory, Research, and Practice (pp. 1-366). Springer. https://doi.org/10.1007/978-3-319-08269-1 
Klontz, B., Britt, S. L., Mentzer, J., \& Klontz, T. (2011). Money Beliefs and Financial Behaviors: Development of the Klontz Money Script Inventory. Journal of Financial Therapy, 2(1), 1-22. https://doi.org/10.4148/jft.v2i1.451

Klontz, T., Britt, S. L., Archuleta, K. L., \& Klontz, B. (2012). Disordered Money Behaviors: Development of the Klontz Money Behavior Inventory. Journal of Financial Therapy, 3(1), 16-42. https://doi.org/10.4148/jft.v3i1.1485

Kobler, D., Hauber, F., \& Ernst, B. (2016). Millennials and Wealth Management: Trends and Challenges of the New Clientele. Deloitte.

Kübilay, B., \& Bayrakdaroğlu, A. (2016). An Empirical Research on Investor Biases in Financial Decision-Making, Financial Risk Tolerance and Financial Personality. International Journal of Financial Research, 7(2), 171-182. https://doi.org/10.5430/ijfr.v7n2p171

Lin, H. (2011). Elucidating the Influence of Demographics and Psychological Traits on Investment Biases. World Academy of Science, Engineering and Technology, 5(5), 145-150.

Mccoy, M. A., Ross, D. B., \& Goetz, J. W. (2013). Narrative Financial Therapy: Integrating a Financial Planning Approach with Therapeutic Theory. Journal of Financial Therapy, 4(2), 22-42.

Michael, B., Hartwell, C. A., \& Ho, G. (2015). Wealth Management and Private Banking Services in Developing Markets. The Journal of Investment Consulting, 16(1), 10-19.

MIFC. (2016). Islamic Wealth Management: Growing Stronger Globally. Kuala Lumpur: Malaysia Islamic Financial Center (MIFC).

Moghaddam, F. M., \& Harre, R. (1995). But is it Science? Traditional and Alternative Approaches to the Study of Social Behavior. World Psychology, 1(4), 47-78.

Musse, O. S. H., Echchabi, A., \& Aziz, H. A. (2015). Islamic and Conventional Behavioral Finance: A Critical Review of Literature. Journal of King Abdulaziz University, Islamic Economics, 28(2), 249-266. https://doi.org/10.4197/Islec.28-2.10

Neumann, J., \& Morgenstern, O. (1947). Theory of Games and Economic Behavior (2nd ed.). Princeton University Press.

Nevins, D. (2004). Goals-Based Investing: Integrating Traditional and Behavioral Finance. The Journal of Wealth Management, 6(4), 1-24.

Othman, A., \& Subramaniam, P. P. (2013). Wealth Management from The Shariah Perspective. Q Report, 94-99.

Perry, V. G., \& Morris, M. D. (2005). Who is in control? the role of self-perception, knowledge, and income in explaining consumer financial behavior. Journal of Consumer Affairs, 39(2), 299-313. https://doi.org/10.1111/j.1745-6606.2005.00016.x

Peterson, R. L. (2009). Emotional Communication: Strategies to Build Your Advisory Business. Investments and Wealth Monitor, May/June, 27-28.

Pompian, M. M. (2009). Behavioral Investor Types: A Research Study and A New Concept in the Practical application of Behavirol Finance. Investments and Wealth Monitor, 6-11.

Pompian, M. M. (2012a). Behavioral Finance and Investor Types. Private Wealth Management Feature Articles, 2012(1), 1-3.

Pompian, M. M. (2012b). Behavioral Finance and Wealth Management: How To Build Investment Strategies That Account for Investor Biases (2nd ed.). New Jersey: John Wiley \& Sons Inc.

Pompian, M. M. (2016). Risk Profiling through a Behavioral Finance Lens. CFA Institute Research Foundation.

Pompian, M. M., \& Longo, J. M. (2004). A New Paradigm for Practical Application of Behavioral Finance : Creating Investment ProgramsBased on Personality Type and Gender to Produce Better Investment Outcomes. The Journal of Wealth Management, 7(2), 9-15.

Pompian, M. M., \& Longo, J. M. (2005). The Future of Wealth Management : Incorporating Behavioral Finance into Your Practice. Journal of Financial Planning, 18(3), 1-14.

Posner, R. A. (2013). Behavioral Finance Before Kahneman. Loyola University Chicago Law Journal, 44, 1341-1347. https://doi.org/10.1525/sp.2007.54.1.23.

Prarisse, A., \& Richman, D. (2006). Questions Great Finanacial Advisors Ask.. And Investors Need to Know. 
USA: Kaplan Publishing.

PWC Global FinTech Report. (2016). How FinTech is shaping Financial Services.

Qaseem, M. (2016). Shariah Perspective in Wealth and Its Management. Islamic Wealth Management Report, 26-37.

Qutb, M. (1993). Dirasat Fi An-nafs Al-ensaneyyah (Studies in Human Nature) (10th ed.). Cairo, Egypt: Dar Al-Shurooq.

Qutb, S. (2006). Muqawwimat At-tasauur Al-Islami (The pillars of Islamic worldview) (6th ed.). Cairo, Egypt: Dar Al-Shurooq.

Raffa, G. (2014). Mentoring the Next Generation of Advisors: Thoughts on How to Approach Succession Planning. Investments and Wealth Monitor, (Jan/Feb), 39-40.

Rättyä, J. (2016). March of the Robo-advisors: The potential for global expansion of digital asset management platforms. Helsinki Metropolia University of Applied Sciences.

Razak, A. L. A., Mohamed, M., \& Mutiu, S. (2013). Cognitive-behavioural therapy: A glimps into some early muslim scholars' contributions. In Proceeding of the world conference on integration of knowledge (pp. 527-535). Langkawi, Malaysia.

Robinson, K. (2016). Managing the Millennial Generation. Investments and Wealth Monitor, (Nov/Dec), 5-7.

Sahi, S. K., Arora, A. P., \& Dhameja, N. (2013). An Exploratory Inquiry into the Psychological Biases in Financial Investment Behavior. Journal of Behavioral Finance, 14(2), 94-103. https://doi.org/10.1080/15427560.2013.790387

Samsuddin, M. Z. (2012). Psychology, Culture and Indigenisation: An Overview from the Islamic Perspective. In N. M. Noor (Ed.), Psychology from an Islamic Perspective: A Guide to Teaching and Learning (3rd ed., pp. 43-58). Kuala Lumpur: IIUM Press.

Sandwick, J. (2011). Islamic Wealth Management, (February).

Shafii, Z., Yusoff, Z. M., \& Noh, S. M. (2013). Islamic Financial Planning \& Wealth Management (1st ed.). Kuala Lumpur: IBFIM.

Shefrin, H. (2000). Beyond Greed and Fear: Understanding behavioral finance and the psychology of investing. Oxford Unversity Press.

Shefrin, H. (2001). Behavioral Corporate Finance. Journal of Applied Corporate Finance, (September), 1-17. https://doi.org/10.2139/ssrn.288257

Shefrin, H. (2008). A behavioral approach to asset pricing (2nd ed.). USA: Elsevier Inc.

Shefrin, H. (2010). Behavioralizing Finance. Foundations and Trends in Finance, 4(1-2), 1-184. https://doi.org/10.1561/0500000030

Shefrin, H., \& Statman, M. (1994). Behaviral Capital Asset Pricing Theory. The Journal of Financial and Quantitative Analysis, 29(3), 323-329.

Shefrin, H., \& Statman, M. (2000). Behavioral Portfolio Theory. Journal of Financial and Quantitative Analysis, 35(2), 127-151.

Shiller, R. J. (1998). Human Behavior and the Efficiency of the Financial System (NEBR Working Paper Series No. 6375). Cambridge.

Shiller, R. J. (2003). From Efficient Markets Theory To Behavioral Finance. Journal of Economic Perspectives, 17(1), 83-104. https://doi.org/10.1257/089533003321164967

Shiller, R. J. (2005). Irrational exuberance (2nd ed.). Princeton and Oxford. https://doi.org/10.2469/cp.v23.n3.4255

Siddiqi, M. N. (2006). Islamic Banking and Finance in Theory and Practice: a Survey of State of the Art. Islamic Economic Studies, 13(2), 1-48. https://doi.org/10.4197/islec.17-1.4

Sinha, D. (1997). Indigenizing psychology. In J. W. Berry, Y. Poortinga, \& J. Pendey (Eds.), Handbook of cross-cultural pyschology (2nd ed., pp. 129-169). Boston: Allyn and Bacon.

Sironi, P. (2016). Fintech Innovation: From Robo-Advisors to Goal-based Investing and Gamification (1st ed.). Wiley Online Library (The Wiley Finance Series). 
Spellacy, M., \& Patel, A. (2016). Wealth Management Trends: A Revolution Both Loud and Quiet. PWC.

Statman, M. (1999). Behaviorial Finance: Past Battles and Future Engagements. Financial Analysts Journal, 55(6), 18-27. https://doi.org/10.2469/faj.v55.n6.2311

Statman, M. (2002). Financial Physicians. In Investment Counseling for Private Clients IV (pp. 5-11). CFA Institute Publications.

Statman, M. (2004). What Do Investors Want? The Journal of Portfolio Management, 30(5), 153-161. https://doi.org/10.3905/jpm.2004.442641

Statman, M. (2008a). Countries and Culture in Behavioral Finance. CFA Institute Conference Proceedings Quarterly, 25(3), 38-44. https://doi.org/10.2469/cp.v25.n3.6

Statman, M. (2008b). Socially Responsible Investors and Their Advisors. The Journal of Investment Consulting, $9(1), 15-26$.

Statman, M. (2015). Culture in Risk, Regert, Maximization, Social Trust and Life Satisfaction. The Journal of Investment Consulting, 16(1), 20-30.

Statman, M., \& Pan, C. H. (2012). Questionnaires of Risk Tolerance, Regret, Overconfidence, and Other Investor Propensities. Journal of Investment Consulting, 13(1), 54-63.

Statman, M., \& Wood, V. (2004). Investment Temperament. Journal of Investment Consulting, 7(1), 55-66. Retrieved from http://moneycaresolutions.in/knowledge/Investment-temperament.pdf

Statman, M., Anginer, D., \& Fisher, K. L. (2008). Affect in a behavioral asset pricing model. Financial Analysts Journal, 64(2), 20-29. https://doi.org/10.2139/ssrn.1094070

Tasdemir, M., Cobanoglu, M. M., \& Iqbal, Z. (2016). Wealth in Islam. Islamic Wealth Management Report, $38-45$.

Thomson Reuters. (2015). Unlocking Potential Global Islamic Asset Management Outlook 2015. Dubai, United Arab Emirates.

Towel, M., Statman, M., Dieschbourg, M., Kahn, R., Chinacarini, L., \& Baker, E. (2015). Richard Thaler: Founding Father of Behavioral Economics. The Journal of Investment Consulting, 16(1), 4-9.

Traff, J. D. (2016). The Future of the Wealth Management Industry: Evolution or Revolution? Massachusetts Institute of Technology.

Vincent, G., Cunniff, S., \& Goldstein, J. (2015). Ten Disruptive Trends in Wealth Management. Deloitte.

Waller, R., Trepka, C., Collerton, D., \& Hawkins, J. (2010). Addressing Spirituality in CBT. The Cognitive Behaviour Therapist, 3, 95-106. https://doi.org/10.1017/S1754470X10000073

Warde, I. (2000). Islamic finance in the global economy. Edinburgh University Press. Edinburgh: Edinburgh University. https://doi.org/10.3366/edinburgh/9780748612161.001.0001

Weisinger, H. (2004). The Emotionally Intelligent Financial Advisor (1st ed.). USA: Dearborn Trade Publishing.

Welch, B. S. (2015). Managing Client Relationships in a Goals-Based Framework. Investments and Wealth Monitor, (Nov/Dec), 11-15.

Wilcox, J. W. (2005). Risk Management for Private Wealth. In CFA Institute Conference Proceedings (pp. 41-47).

Yamagishi, T., Li, Y., Takagishi, H., Matsumoto, Y., \& Kiyonari, T. (2014). In Search of Homo economicus. Psychological Science, 25(9), 1699-1711. https://doi.org/10.1177/0956797614538065

Zaidi, F. B., \& Tauni, M. Z. T. (2012). Influence of Investor's Personality Traits and Demographics on Overconfidence Bias. IJCRB Interdisciplinary Journal of Contemporary Research in Business, 4(6), 730-746. Retrieved from http://journal-archieves24.webs.com/730-746.pdf

\section{Appendix}

The suggested checking list that are adapted from SLCT and EVOKE methods beside some modifications and additions.

a) Personal information

Family, traditions, religiosity, achievements, leisure, etc. 
b) Values

Examples of thought-provoking questions that would enable the advisor to understand the most deeply held values of the clients are:

i. Being financially secure, how would you live your life? What would you do with the money? Would you change anything? Let yourself go.

ii. If you have five to ten years to live, what will you do in the time you have remaining to live? Will you change your life? How will you do it?

iii. What if you have one day to live, what dreams will be left unfulfilled? What do you wish you had finished or had been? What do you wish you had done? What did you miss?

c) Other living objectives

Goals, plan, work/life balance, philanthropy, hobbies, interests, technology usage

d) Demographics

Generation (baby boomers, $\mathrm{X}$ or millennials), race, gender, age and other demographic influencers

e) Past experience with former wealth managers

Advantages, disadvantages, unfulfilled goals and wishes, etc.

f) Residence information

Residence, community, future destination etc.

g) Employment information etc.

Career plans, current job likes/dislikes, succession

h) Savings/Budgets

Goals of saving, spending and gifts; reserves, liabilities, plans etc.

i) Asset protection/Survivor income

Wealth preservation; wealth transfer/inheritance; insurance/takaful; bequests; proxies, Waqf

j) Retirement savings/Spending plans

Retirement goals, plans, needs; work; leisure

k) Taxes and Zakah

1) Education

Goals, plans, savings

\section{Copyrights}

Copyright for this article is retained by the author(s), with first publication rights granted to the journal.

This is an open-access article distributed under the terms and conditions of the Creative Commons Attribution license (http://creativecommons.org/licenses/by/4.0/). 